\title{
Temporary replacement of congenital missing incisors on mandible using temporary anchorage devices in growing patient: 2-year follow-up
}

\author{
Youn-kyung Choi'*, Eun-Young Kwon', Kyung-Hwa Jung'1, Na-Rae Choi', Soo-Byung Park², Seong-sik Kim², \\ Yong-il Kim² \\ 'Dental Clinic Center, Pusan National University Hosptial, Busan, Republic of Korea \\ ${ }^{2}$ Department of Orthodontics, School of Dentistry, Pusan National University, Yangsan, Republic of Korea
}

Agenesis of permanent tooth in adolescent patients can be treated either by orthodontic treatment for space closure or by maintaining the space until implant restoration can be carried out in adult. However, gradual atrophy of alveolar bone width makes it difficult to restore the prosthesis in the future or may cause unaesthetic results. Therefore, maintaining of not only the missing space but also the alveolar bone width should be considered. This case is a treatment whereby a temporary replacement of missing 2 mandibular incisors in adolescent patient was carried out using 2 temporary anchorage devices (TADs). Two TADs were placed horizontally 2 - $3 \mathrm{~mm}$ below the top of alveolar ridge, and fixed with artificial teeth by stainless steel wires extended. During the 2 year follow-up, neither gingival inflammation nor loss of the TADs have occurred. In the radiographic evaluation, the growth of the adjacent alveolar bone was not inhibited, and the width of the alveolar bone was maintained. (J Dent Rehabil Appl Sci 2020;36(4):27281)

Key words: alveolar bone loss; tooth agenesis; dental implants; temporary restoration; adolescent

\begin{abstract}
서론
치과의사에게 성장이 남아있는 청소년기 환자의 선천 결손된 영구치를 치료하는 것은 어려운 문제이다. 영구치 의 상실은 그 정도와 위치에 따라 차이가 있을 수 있으나, 악골 발육 및 저작 기능 감소, 발음 이상, 수직 고경 상실 및 악궁의 형태 변화와 교합의 이상 등의 다양한 문제점 을 야기할 수 있다. ${ }^{1}$ 따라서 임상 검사와 방사선 검사를 통한 조기 진단이 중요하며, 교정과, 보철과, 구강 외과 등의 다분야 협력 치료가 필요하다.

치아 결손의 유병률은 $1.4-15.9 \%$ 로 다양하게 보고되 며, 가장 흔하게 결손되는 치아는 제 3 대구치를 제외하고

*Correspondence to: Youn-kyung Choi

Clinical Associate Professor, Clinic Center, Pusan National University Hosptial 179 Gudeok-ro, Seo-gu, Busan, 49241, Republic of Korea

Tel: +82-51-240-7430, Fax: +82-51-240-7706, E-mail: youngyng@hanmail.net Received: October 28, 2020/Last Revision: November 10, 2020/Accepted:

December 4, 2020
\end{abstract}

하악 제 2 소구치, 상악 측절치, 상악 제 2 소구치 순으로 알 려져 있으나, ${ }^{2,3}$ 각 연구마다 환자 선정 방법, 연령, 성별, 인종적 차이로 결과가 조금씩 다르게 나타난다.

선천 결손 영구치를 치료하는 방법은 주로 악궁 내에 서 결손치의 공간 정도에 따라 교정 치료로써 공간을 폐 쇄할 수도 있으며, 공간을 유지시키고 주변 지대치를 삭 제하여 고정성 보철물을 삽입하거나 혹은 지대치 삭제 없이 임플란트 수복을 통해서 해결할 수 있다. 이 중 어 떤 치료 방법을 선택하느냐는 환자의 연령, 만기 잔존한 유치의 상태, 결손 공간의 크기, 안모 형태, 구강 내 존재 하는 부정교합의 정도와 환자의 선호도 등에 따라 달라 질 수 있다. 최근에는 교정 치료 영역에서 골성 고정원 
(temporary anchorage devices, TADs)을 사용함으로써 공간 폐쇄를 과거보다 더욱 쉽게 시행할 수 있지만 이는 환자의 측모(profile)에 따라 치료 방법으로 선택되지 못 할 수 있다. 이 경우, 고정성 보철물 혹은 임플란트 보철 물 등이 필요하지만, 청소년기 환자는 성장으로 인한 인 접 치조골의 발육과 치아의 맹출이 지속되므로 보철물로 인해 결손 부위의 치조골 성장이 저해될 수 있어 영구적 인 보철 수복의 시기는 치조골 성장이 끝나는 시기로 늦 추는 것이 추천된다. ${ }^{5,6}$ 그러나 보철 수복이 가능한 시기 까지 장기간 그대로 둘 경우, 주변 치아의 경사와 치조골 의 폭과 높이가 감소할 수 있어, 결과적으로 임플란트 수 복 시, 골이식 등의 추가적인 시술이 필요할 수 있다. 그 밖에 방법으로 인공치를 포함한 가철성 장치를 사용하거 나, 메릴랜드 브릿지(Meryland bridge) 등의 접착식 보철 수복이 있다. 그러나 가철성 장치의 경우, 환자의 착용 협 조도에 의존해야 하는 등 결손 공간의 유지에는 효과적 이지 않다고 알려져 있으며, 접착식 보철물은 주변 치아 의 삭제가 요구되고, 쉽게 탈락될 수 있다는 단점이 존재 하며 두 방법 모두 치조골의 위축을 방지하기가 어렵다.

이에, 대안으로 골성 고정원(TADs)을 이용한 임시 수 복물의 제작이 제안되었으나, 이러한 임시 수복물의 부 작용에 대한 보고가 있었다., 골성 고정원은 임플란트와 는 달리 현미경학적 소견에서 골유착을 보이지 않는다고 알려져 있지만, ${ }^{10}$ 반대로 임플란트나 유착치와 마찬가지 로 치조골의 수직 성장을 저해한다는 보고 역시 존재하 기 때문에, ${ }^{8}$ Kokich와 Swift ${ }^{9}$ 는 치조정에 수직으로 식립 한 골성 고정원을 이용한 임시 수복물의 사용을 경고하 였다. 그러나 최근 Melsen 등 ${ }^{11}$ 은 동물 실험을 통해 치아 가 발거된 치조골에 수평 방향으로 골성 고정원를 식립 할 경우, 유착과 같은 치조골의 수직 성장 저해를 보이지 않으며, 골성 고정원 주위뿐만 아니라, 향후 임플란트를 식립할 부위까지 치조골의 밀도가 높아지고 폭이 유지된 다는 연구 결과를 발표하였다. 또한 임상 연구를 통해 수 평으로 식립된 골성 고정원을 이용한 임시 수복물로 치 열 공간 유지뿐만 아니라, 치조골의 수직 성장 저해를 방 지하며, 치조골의 높이와 폭경 유지에도 효과가 있음을 보고하였다. ${ }^{12}$ 뿐만 아니라 본 교실에서도, 하악 좌우 제2 소구치가 선천 결손된 환자에서, 교정 치료를 위해 골성 고정원을 식립하고 유지했던 쪽에서 치조골의 폭경 감소 가 적었던 증례가 있었다(Fig. 1). 따라서 골성 고정원을 이용한 임시 수복물이 잘 유지될 경우, 결손 공간의 유지 가 용이하며, 대합치의 정출 역시 막을 수 있고, 환자의

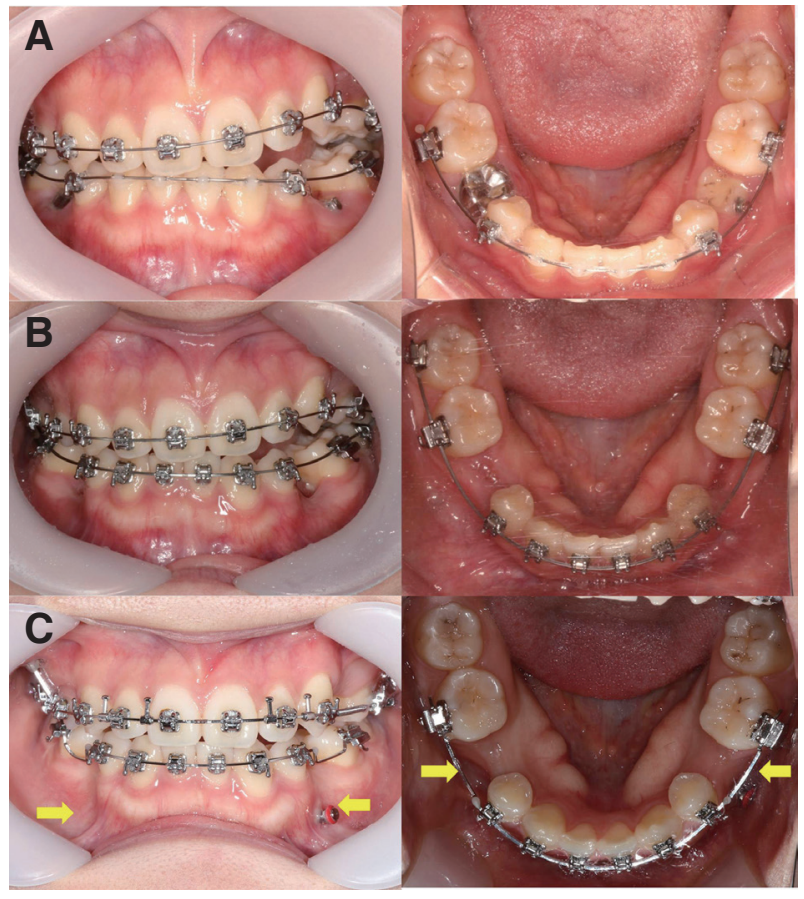

Fig. 1. Clinical pictures $(A-C)$ of a patient suffering from agenesis of both mandibular second premolars and buccal open bite on left side. (A) Both mandibular second primary molars were ankylosed and infraocclusion. (B) Extraction of ankylosed primary molars. And 1 month later, temporary anchorage devices (TADs) was inserted on left side for using as an anchorage for inter-maxillary elastics. (C) After 1 year, the width and height of the alveolar bone were better retained with TADs than without TADs (yellow arrows).

협조도에 의존하지 않아도 되는 장점이 존재한다. ${ }^{12}$

따라서 본 증례는 하악 전치의 선천 결손을 보이는 청 소년기 환자에서 골성 고정원을 이용한 고정식 임시 수 복물의 제작과 사용 방법을 설명하고, 2 년 동안의 임상적 및 방사선적 치조골 변화에 대해 보고하고자 한다.

\section{증례보고}

“영구치가 없어요. 임플란트를 하고 싶은데 지금은 할 수 없대요"를 주소로 교정과에 내원한 만 14세 여자 환 아이다.

구강내 임상 소견상, 주소인 하악 우측 측절치와 견치 가 선천결손 되었으며, 유치는 탈락한 상태로, 결손된 공 극은 $10.5 \mathrm{~mm}$ 였다. 하악 우측 측절치의 치조골 폭경이 다소 좁아져 있었다. 그 밖에 하악 좌측 견치 후방의 공 극과 하악 치열 정중선의 우측 변위 $(1 \mathrm{~mm})$ 가 존재했으 
나, 전반적인 구치 교합은 I급 구치 관계로 양호하였다. 보호자 진술에 따르면 하악 우측 유측절치와 유견치가 탈락한 지는 한 달 정도 지났다고 하였다.

구강외 임상 소견에서 하악각이 작은 단안모였고, 턱 끝이 발달하여 도드라져 보였으며(Facial convexity: $-1.3^{\circ}$ ), 구순돌출감은 존재하지 않았다(Fig. 2).

콘빔 전산화 단층영상(Cone Beam Computed Tomography, CBCT, DCT PRO; Vatech Co, Seoul, South Korea)을 촬영하여 축상(Axial view)에서, 결손공간의 치 조골 최상방 $2.5 \mathrm{~mm}$ 아래의 협설측 치조골 폭경은 가장 좁은 부위에서 $7.11 \mathrm{~mm}$ 로 계측되었다. 인접치 치조골과 비교하여 수직적인 높이 차이는 관찰되지 않았다(Fig. 3).

환아의 신장은 $154 \mathrm{~cm}$ 였으며, 보호자분의 말씀에 따 라 작년까지는 급격한 키 성장을 보였으나, 올해는 그 정 도가 줄었다고 하였다. 안면골의 최대 성장은 신장의 최 대 성장기와 비슷하거나 다소 늦고, ${ }^{13}$ 경추 성숙 분류 단 계(the Cervical vertebral maturation method, $\mathrm{CVMs}$ )에 서 $^{14} 2$ - 4번 경추가 직사각형이고 하연에 함몰부가 보이 는 것을 토대로 stage 4 라고 판단되어, 환아의 안면골 사
춘기 최대 성장기는 지났다고 판단하였다(Fig. $3 \mathrm{C}$ ). 그러 나 CVMs stage 4는 잔여 성장이 남아있을 수 있어, 영구 적인 보철 수복물은 시행하지 않는 것이 추천되며, ${ }^{14}$ 안면 의 수직 성장과 치아의 맹출은 봉합부 성장과는 다르게 사춘기 성장 급등기를 지나고서도 지속된다고 하므로, ${ }^{6}$ 영구적인 보철 수복물은 이르다고 평가하였다.

이에 현재의 구치 교합 상태가 양호하므로 치료 계획 은, 별도의 교정 치료 없이 임플란트 보철을 수복할 때까 지 결손치 공간에 골성 고정원을 이용한 임시 고정식 공 간 유지 장치를 사용하여 결손 공간 소실을 방지하고 치 조골의 폭을 최대한 유지하는데 목표를 두기로 하였다.

Ciarlantini 등 ${ }^{12}$ 의 연구 방법에 따라 결손 치아 공간에 collar가 높은, 직경 $1.6 \mathrm{~mm}$, 길이 $6.0 \mathrm{~mm}$ 의 골성 고정원 (Jeil Medical Co., Seoul, Korea)을 치조정에 수평하게 협 측에서 설측 방향으로 2 개 식립하였다. 식립 위치는 수직 적으로 치조정 최상방에서 $2-3 \mathrm{~mm}$ 아래에, 각각 인접 치 치근에서 $1.5-2 \mathrm{~mm}$ 떨어진 부위에 식립하였다. 골성 고정원을 식립하고 난 후, 모형을 채득하여 모형 상에서 인공치를 제작하였다. 골성 고정원과 인공치를 고정하기

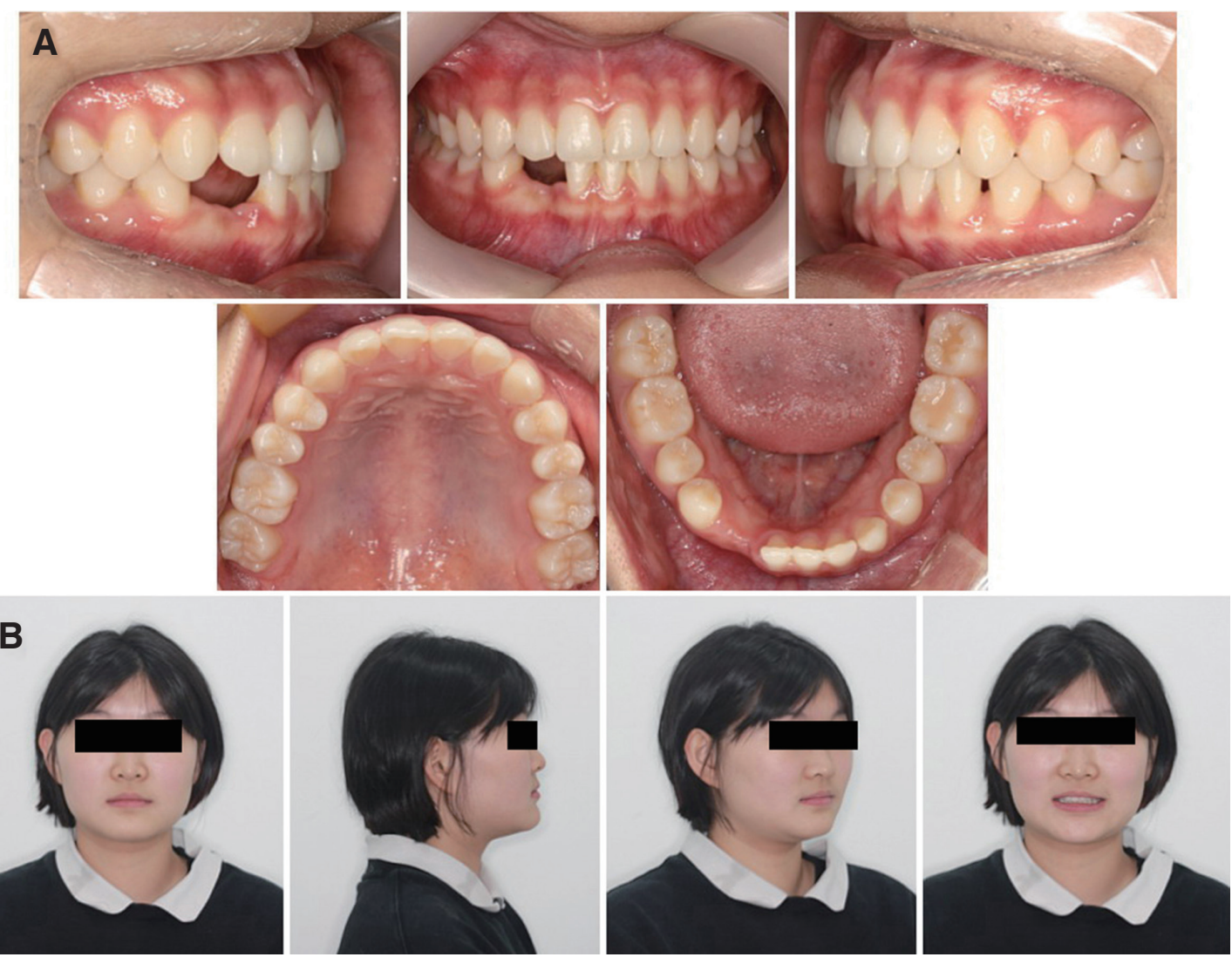

Fig. 2. Pre-treatment intraoral (A) and extraoral (B) photographs. (A) 2 Mandibular anterior teeth were congenitally missing. (B) Prominent chin and concave profile. 


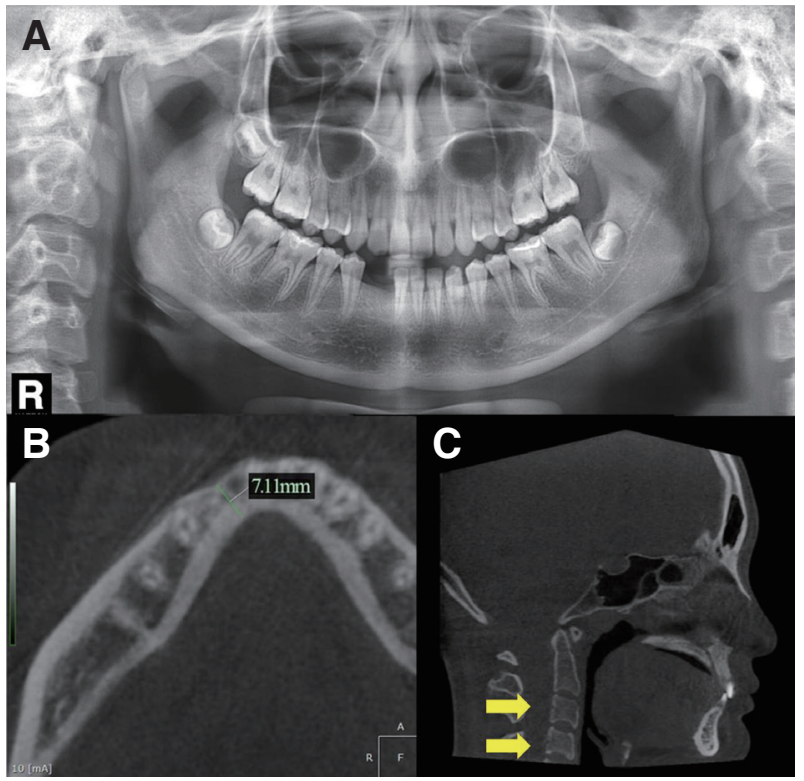

Fig. 3. Pre-treatment panoramic $(A)$ and $C B C T(B, C)$ radiographs. (A) Panoramic radiograph. (B) Cone-beam computed tomograph (axial view) : Alveolar bone width (most narrow area) was $7.11 \mathrm{~mm}$. (C) Inferior borders of the second, third and fourth vertebra's bodys were concave and body's shapes were rectangular (yellow arrows). Therefore, she was estimated on CVM stage 4 (after growth peak period).

위해 각각의 인공치에 $0.019 \times 0.022$-inch stainless steel 호선을 삽입하였으며, 호선으로 치조골의 형태를 따라 골성 고정원 collar 부위에 고정 할 수 있는 loop를 제작 하였다. 호선은 치은에서 $0.5-1 \mathrm{~mm}$ 정도 띄웠으며, 교 합 간섭이나 과도한 교합점이 인공치 상에 형성되지 않 도록 교합을 낮추어 제작하였다.
일주일 뒤, 식립된 골성 고정원은 동요도를 보이지 않 았고, 주변으로 염증 소견 역시 관찰되지 않았다. 미리 제 작해두었던 인공치를 구강 내에서 다시 적합을 점검하 였으며, 삽입된 호선을 골성 고정원에 위치시켰을 때, 인 공치가 견고하게 고정되고, 동요도가 나타나지 않아, 고 정을 진행하였다. 우선 골성 고정원의 collar에 위치시킨 호선의 loop는 교정용 plier로 견고하게 조여주었다. 이 후 호선에 metal primer (Kuraray America, New York, USA)와 bonding agent (Adper Scotchbond; 3M ESPE, St. Paul, USA)을 적용하고, 골성 고정원의 collar와 호 선 사이를 flowable composite resin (Unifil Flow; GC, Tokyo, Japan)을 사용하여 고정하였다(Fig. 4).

장착 후, 환아에게 매일 인공치와 치은 점막 사이에 치 실과 워터픽과 같은 구강 세정기 등을 사용하도록 교육 하였다. 한 달 뒤, 구강 위생 점검 등을 위해 경과 관찰을 하였고, 골성 고정원 주변으로 치태 침착이나 염증 소견 은 관찰되지 않았다. 이후 매 3 개월마다 내원하여 인공치 제거하여 세척 후 재접착하였다. 2년 6개월째 경과 관찰 중이며, $\mathrm{CBCT}$ 는 최초 내원시와 경과 관찰 1년, 2 년 후 촬영하였다.

\section{결과}

2년의 경과 관찰 기간 동안 골성 고정원의 동요도 및 탈락은 나타나지 않았다. 인공치와 호선 주위로 염증이 나 과도한 치은의 증식 역시 관찰되지 않았는데, 이는 환 아의 철저한 구강 위생과 매 3 개월마다 인공치를 재접착 한 결과로 판단된다(Fig. 5).

치조골의 폭경 소실 정도를 평가하기 위해, 최 초 내원과 2 년 경과 관찰 후 촬영한 $\mathrm{CBCT}$ 영상을
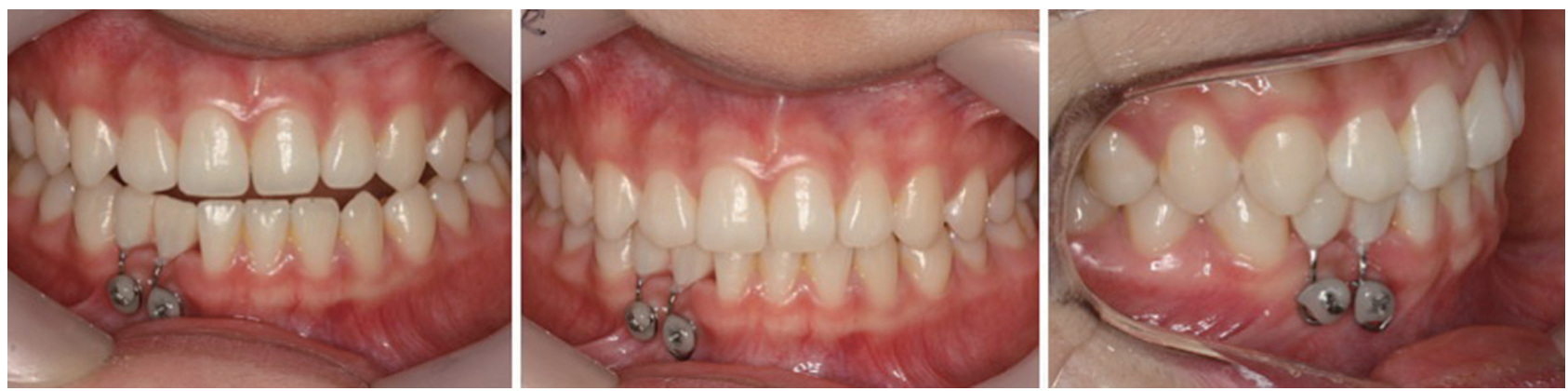

Fig. 4. Temporary anchorage devices (TADs) were placed at $2-3 \mathrm{~mm}$ under the alveolar crest and temporary artificial teeth with loop were placed. 


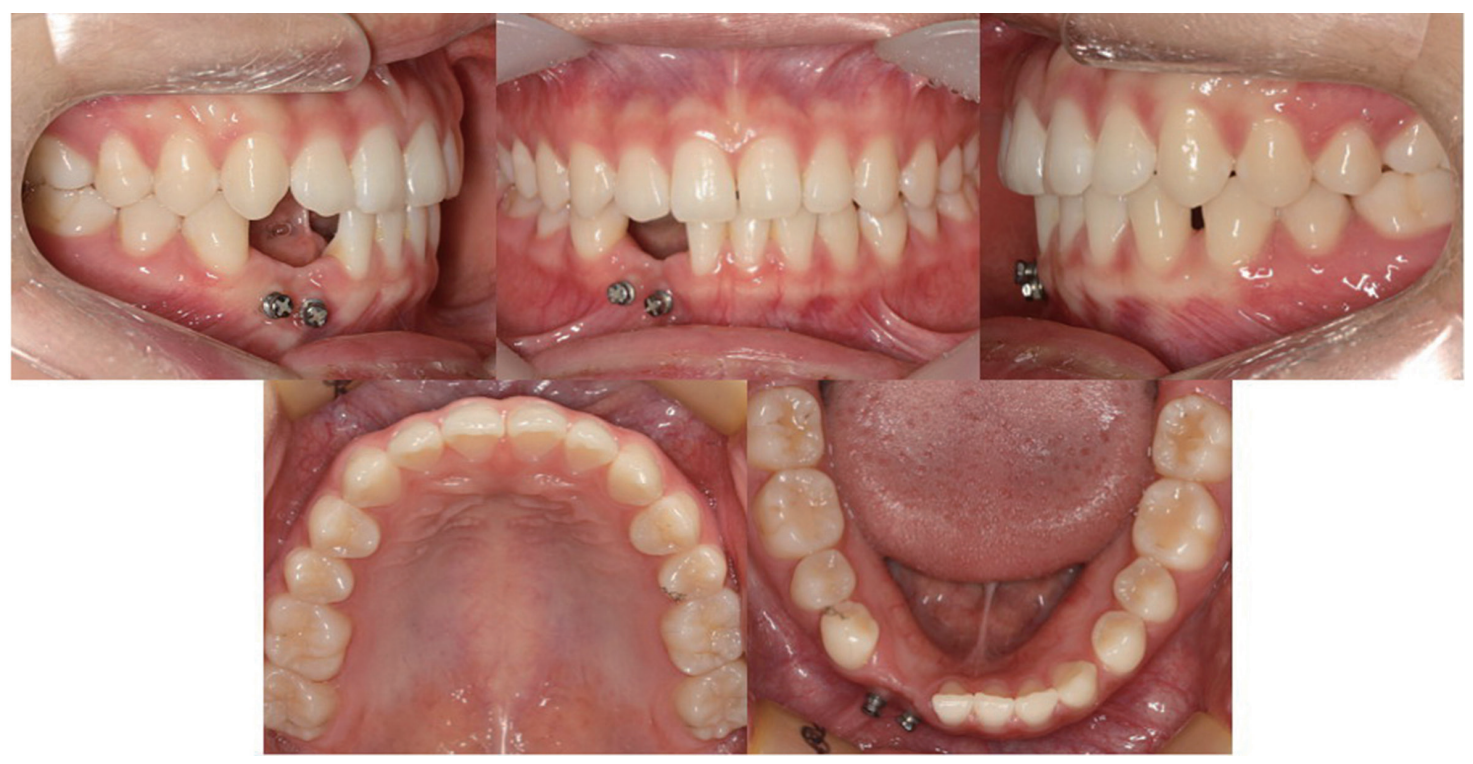

Fig. 5. Intraoral photographs of 2-year follow-up. No inflammation of the soft tissues around the TADs was detected.

OnDemand3D (Cybermed, Seoul, Korea) software를 사용하여, 중첩하였다. 하악골의 3차원적 중첩을 위한 구 조물에 대해서는 논란이 존재하나, 치아와 치조골을 포 함하지 않는 하악체, 턱끝(chin), 하악결합(symphysis) 부 위는 안정적이므로 중첩의 기준으로 사용될 수 있다고 알려져 있다. ${ }^{15}$ 이에 본 증례에서도 치아를 제외한 턱끝 과 하악결합 부위를 OnDemand3D (Cybermed, Seoul, Korea) software에 탑재된 voxel-based superimposition 기능의 automatic superimposition tool을 활용하여 중 첩하였다(Fig. 6). 치조골의 폭을 평가한 결과, 골성 고정 원이 식립된 수직 위치의 축상(axial view) 영상에서, 초진 시 하악골 폭경의 가장 좁은 부위는 $7.11 \mathrm{~mm}$ 였으며, 2년 경과 후 $6.96 \mathrm{~mm}$ 였다(Fig. 7A, 7B).

골성 고정원으로 인한 치조골의 수직 성장 저해가 발 생하였는지 평가를 위해 골성 고정원이 식립된 시상면을 기준 단면으로 하여, 하악골 하연에서 치조정까지의 거 리를 측정하였고, 초진 시 $27.17 \mathrm{~mm}, 2$ 년 경과 후 27.13 $\mathrm{mm}$ 로 계측되었다(Fig. 7C, 7D). 골성 고정원에서 치조 정 최상방까지의 수직 거리는 $2.31 \mathrm{~mm}$ 로 최초 계획했던 치조정 하방 $2-3 \mathrm{~mm}$ 수직 위치 범위 내에서 유지되고 있었다.

\section{고찰}

선천 치아 결손(congenitally missing teeth)은 성장기 아동에서 가장 흔히 관찰되는 발육 장애 중 하나로써, ${ }^{1}$

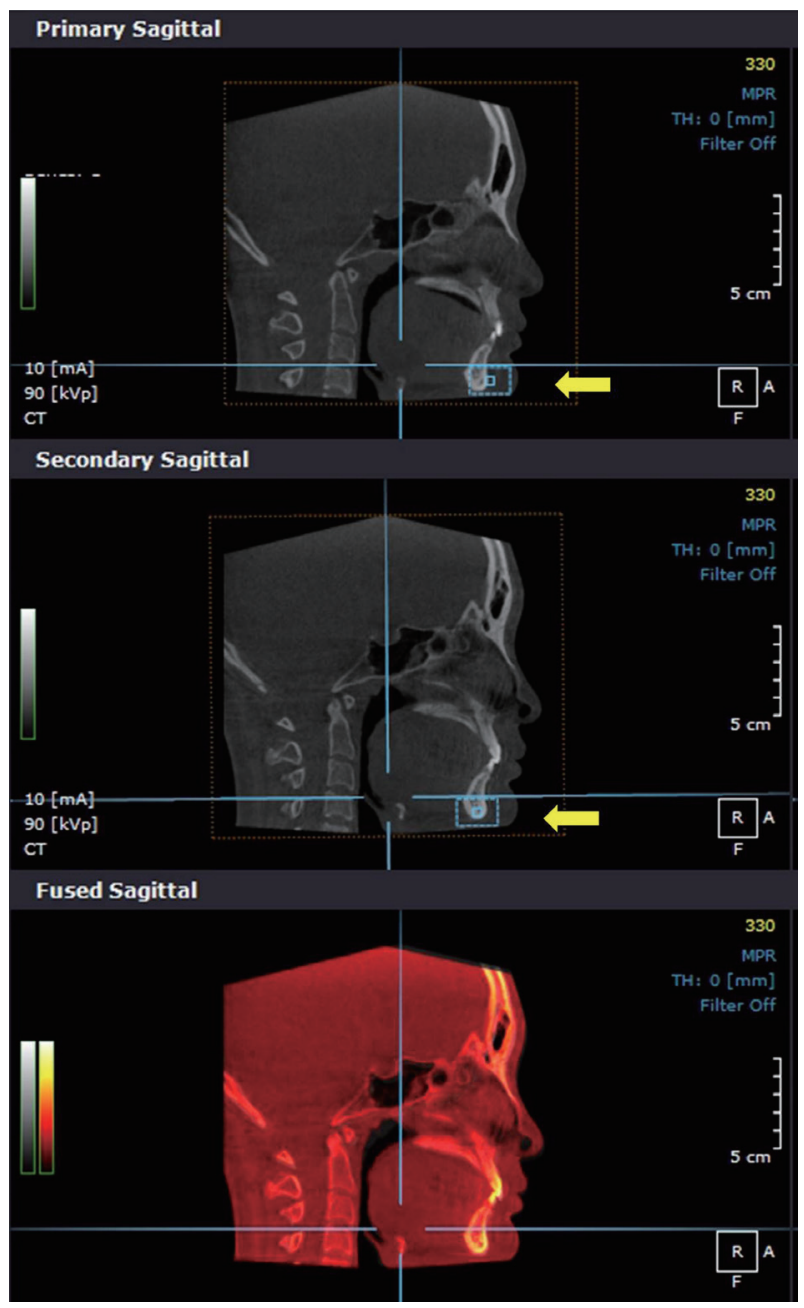

Fig. 6. Superimpositions of pre-treatment and posttreatment CBCTs. Chin and symphysis of mandible excluding teeth (yellow arrows, dotted rectangles) were used as a stabilizing structure for superimposition. 


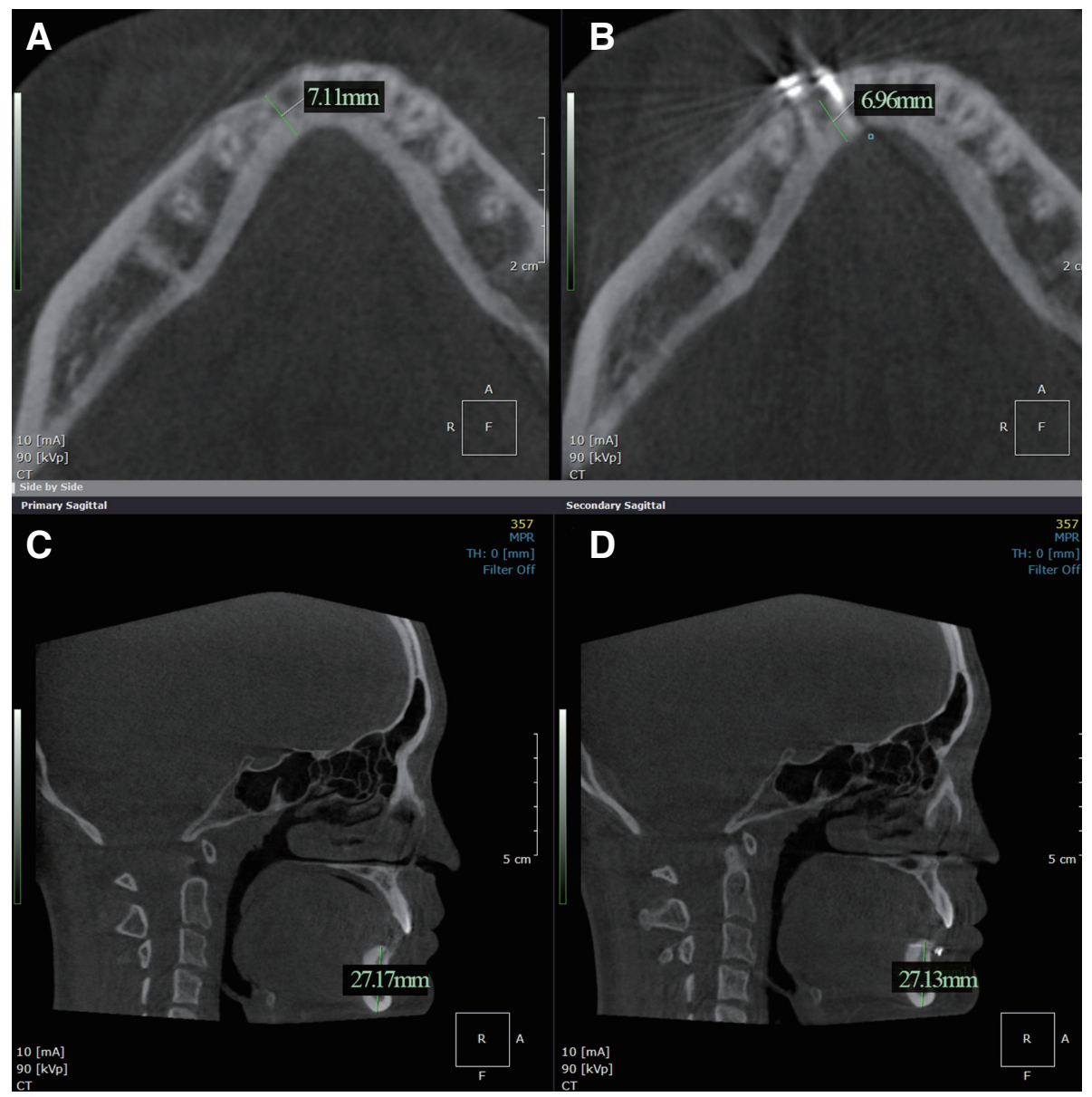

Fig. 7. Comparisons of pre-treatment $(A, C)$ and post-treatment $(B, D)$. Alveolar bone width (most narrow area, $C B C T$ axial view): (A) $7.11 \mathrm{~mm}$, (B) $6.96 \mathrm{~mm}$. Alveolar bone height (CBCT sagittal view): (C) $27.17 \mathrm{~mm}$, (D) $27.13 \mathrm{~mm}$. No significant changes were observed.

심미적 문제와 기능적 장애 등 환자에게 큰 영향을 끼칠 수 있으므로 조기에 문제점을 발견하고, 관리하는 것이 중요하다.

영구치가 선천 결손된 경우, 가장 보존적이고 이상적 인 방법은 잔존 유치를 최대한 오래 유지시키는 것이다. 특히 유구치는 소구치보다 협설, 근원심 폭이 모두 크기 때문에, 치조골 유지뿐만 아니라 영구치 보철 수복을 위 한 공간 유지에도 유리하다. 그러나 유치가 발거되고 초 기 3 개월이 지나면 치조골로 제공되던 혈류 공급이 줄어 들고, 치조골의 흡수와 연조직의 퇴축이 나타난다. ${ }^{16}$ 이 에 유치 탈락 후 3 년동안 치조골의 협설측 폭경은 25 $35 \%$ 가량 줄어들며, ${ }^{17,18}$ 특히 협측에서 흡수되는 정도가 크다. ${ }^{18}$ 또한 소구치가 결손된 환자에서, $3.5 \mathrm{~mm}$ 또는 4.3 $\mathrm{mm}$ 직경의 임플란트를 식립할 경우, 유치가 조기에 탈 락한 환자가 유치가 잔존한 환자보다 $28 \%$ 정도 부가적 인 골이식술 등을 더 필요로 하였다. ${ }^{19}$
그러나 유치가 오래 유지되지 못 하고 발거되면, 치료 방법은 환자의 연령, 잔존한 유치의 상태, 결손공간의 크 기, 안모 형태, 구강 내 존재하는 부정교합의 정도와 환 자의 선호도 등에 따라 달리 결정될 수 있다. ${ }^{4}$

그 중 첫 번째로 선택할 수 있는 방법은 교정 치료를 통 해서 공간을 폐쇄하는 것이다. 특히 교정 치료 영역에서 골성 고정원(temporary anchorage devices, TADs)을 사 용한 후, 공간 폐쇄를 과거에 비교하여 더욱 쉽게 시행할 수 있다. 그렇지만 이는 환자의 측모(profile)에 따라 치 료 방법으로 선택되지 못 할 수 있는데, 측모가 오목할 경우(concave profile) 공간을 폐쇄하면 상하악 전치의 후방 이동과 상하순이 후퇴되어 더욱 오목한 측모를 초 래할 수 있기 때문이다. 본 증례의 환아 역시 턱끝(chin) 이 돌출되어 있었고 구순돌출감이 존재하지 않아 상하 악 전치는 후방 이동되지 않도록 유지되는 것이 필요했 다. 그러나 2 개의 치아가 선천 결손되어 공극이 컸고(10.5 
$\mathrm{mm})$, 공간을 폐쇄할 경우, 안모 악화를 방지하기 위해 우측 하악 구치부 전체가 전방 이동되어야 했으므로, 이 는 달성하기 어렵다고 판단되었다.

두 번째 방법으로, 가철성 유지 장치를 사용할 수 있다. 이는 결손 공간을 유지할 수 있으며, 대합치와 교합이 되 므로 기능의 일정 부분 회복뿐만 아니라 대합치의 정출 역시 막을 수 있다는 장점이 존재한다. 그러나 결손 공간 이 클 경우, 환자의 협조에 의지를 해야 하는 가철성 유지 장치는 공간 유지에 효과적이지 않아 고정성 유지 장치 를 사용하는 것이 필요하다는 연구 결과가 있다. ${ }^{7}$

또 다른 선택 방법은 고정성 보철물 혹은 임플란트 등 을 시행하는 것이다. 그러나 고성정 보철물은 결손치 인 접 지대치의 비가역적인 치아의 삭제가 필요하기 때문에 치조골의 상태나 환자의 전신상태, 경제 상황 등이 불가 능하지 않다면, 젊은 환자에서는 임플란트 보철물을 선 호하는 추세이다. 그러나 청소년기 환자의 경우, 성장으 로 인한 인접 치조골의 발육과 인접 치아의 맹출이 지속 되므로 보철물로 인한 결손 부위의 치조골 성장 저해 등 을 초래할 수 있어 영구적인 보철 수복의 시기는 치조골 의 성장이 끝나는 시기로 늦추는 것이 추천된다. ${ }^{5,6}$ 왜냐 하면 임플란트는 치주 인대가 존재하지 않아, 치조골 내 에서 유착치와 같은 반응을 보이기 때문에, 성장이 남아 있는 청소년기 환자에서는 치조골의 성장을 저해하고, 임플란트 보철물의 상대적인 저위로 인한 심각한 개방 교합을 초래할 수 있기 때문이다..$^{20}$ 이에 과연 언제쯤 청 소년기 환자에서 치조골의 성장이 끝나는 것으로 간주할 수 있는지, 그리고 임플란트 보철물을 식립해도 되는지 에 대한 많은 연구가 시행되었다.- ${ }^{4-6,20,21}$ 안면골의 최대 성 장기는 키의 최대 성장기보다 약간 늦거나 비슷한 시기 에 나타난다고 보고 되고 있으며, 특히 하악골은 상악골 에 비해 늦은 시기까지 진행되어 차등성장이 나타난다. ${ }^{13}$ 뿐만 아니라 안면의 수직 성장과 치아의 맹출은 봉합부 성장과는 다르게 사춘기 성장 급등기를 지나고서도 지속 된다고 하며, ${ }^{6}$ 치열궁 내에서도 폭경이 가장 먼저 성장이 끝나고, 장경, 고경의 순서대로 성장이 끝나므로, ${ }^{20}$ 치조 골의 수직 성장은 늦게 까지 지속됨을 알 수 있다. 따라서 일반적인 권고 사항으로 연속된 측모 두부방사선 사진을 촬영하고 중첩하여 더 이상 확연한 성장이 나타나지 않 을 때 보철 수복을 시행하는 것이 중요하며, 일반적인 나 이로 여성에서는 만 17세경, 남성에서는 만 18 - 21세경 이후 임플란트를 식립하도록 권하고 있다. ${ }^{4,21}$ 본 증례에 서의 환아는 연속된 측모두부방사선 사진을 사용할 수는
없었으나, 만14세의 여성 환자로, 신장 변화와 경추 성숙 분류 단계(CVMs, stage 4)를 토대로 사춘기 성장 급등기 를 지났다고 보았다. 그러나 앞서 언급한 대로 치조골의 수직 성장은 사춘기 성장 급등기 이후에도 지속되므로 임플란트 보철 수복을 바로 시행하기에는 이르다고 판단 하였다.

그러나 영구 보철물이 삽입될 때까지 결손 공간을 비워 둘 경우, 기능적 문제뿐만 아니라 자존감의 상실과 이에 따른 사회성 저하 등의 심리적 문제를 야기할 수 있다. 이 에 최근 교정용 골성 고정원(TADs)을 이용한 임시적인 보철 수복이 제안되었으며, ${ }^{8,12} 5$ 년 이상의 경과 관찰에서 도 임시 보철물의 사용에 있어 양호한 결과를 보고하였 다. ${ }^{12}$ 또한 최근 Melsen 등은 동물 실험 ${ }^{11}$ 과 임상 실험 ${ }^{12}$ 을 통해 치아가 결손된 치조골에 골성 고정원(TADs)을 식 립할 경우, 골성 고정원 주위 뿐만 아니라, 향후 임플란트 를 식립할 부위까지 치조골의 밀도가 높아지고, 치조골 폭경이 유지된다는 연구 결과를 발표하였다. 또한 조직 학적으로도 골성 고정원을 식립한 쪽에서 훨씬 높은 골 개조 소견과 많은 조골, 파골 세포의 개입을 보인다고 하 였으며, 이를 토대로 발치 후 골개조가 덜한 기저골 부위 에 골성 고정원을 식립하는 것이 아닌, 골개조가 활발하 게 일어나는 치조골 상방에서 2-3 mm 아래에 식립하 는 것이 치조골을 유지하는데 더욱 큰 효과가 있다고 하 였다. ${ }^{11}$ 그러나 일반적인 보철용 임플란트와는 다르게 치 조골에 수직방향이 아닌, 수평방향으로 식립하여야 치조 골의 수직 성장 저해를 방지할 수 있다고 하였는데, ${ }^{11}$ 이 는 골성 고정원은 현미경학적 소견으로 임플란트와 같은 골유착을 일으키지는 않는다고 알려져 있으나, ${ }^{10}$ 치조골 상방에서 수직 방향으로 식립된 골성 고정원은 교합력 과 대합치의 정출 등에 의해, $60-80 \%$ 정도에서 골유착 과 같은 골표면과의 접촉을 보여, 임플란트와 마찬가지 로 치조골의 수직 성장을 저해할 수 있기 때문이다. ${ }^{8}$ 또한 Kokich와 Swift ${ }^{9}$ 는 수직으로 식립된 골성 고정원은 골형 성 능력을 가지고 있는 치조정 부위의 골막을 천공시켜, 치조정의 수직 성장을 저해할 수 있으므로 치조정에 수 직방향으로 식립하지 않도록 주의하였다. 따라서 본 증 례에서도 치조골 최상방에서 2-3mm 하방에 협측에서 설측으로 치조골에 평행하게 골성 고정원을 식립하였다. 이후 2 년의 경과 관찰 후 채득한 $\mathrm{CBCT}$ 상에서 인접 치 조골과의 성장에 따른 수직적 위치 차이는 나타나지 않 았다. 하악골 하연에서 치조정까지의 거리는 치료 전과 2 년 경과 후 유의한 차이를 보이지 않아(initial: $27.17 \mathrm{~mm}$, 
2 yr-follow up: $27.13 \mathrm{~mm}$ ), 골성 고정원으로 인한 치조 골의 수직 성장 저해는 발생하지 않은 것으로 판단된 다. 마찬가지로 치조골의 폭경을 평가해본 결과, 치조골 폭경의 미약한 소실은 존재하나(initial: $7.11 \mathrm{~mm}, 2 \mathrm{yr}-$ follow up: $6.96 \mathrm{~mm}$ ) 초기 3 년간 $25-35 \%$ 의 치조골 폭 경 소실을 보고한 기존 논문들과 비교하여, ${ }^{17,18}$ 치조골 폭 이 비교적 잘 유지된 결과를 보인다.

그러나 골성 고정원에 호선을 이용하여 고정한 임시 수 복물은 과도한 교합력을 견딜 수 없으며, 직경이 작은 골 성 고정원이 파절될 수도 있기 때문에 교합력을 적게 받 도록 교합면 사이즈를 작게 하고, 교합조정을 시행하는 것이 좋다. 본 증례에서는 인공치에 과도한 교합이 형성 되지 않도록 조정을 하였으며, 환자에게도 인공치로 딱 딱한 음식을 저작하지 않도록 하는 등의 교육을 시행하 였다.

또한 골성 고정원과 호선 주위로 구강 위생을 철저히 하여 치은을 건강하게 유지하는 것이 중요하다. 인공치 제작 및 호선을 고정시, 치은이 증식하지 않도록 0.5 - 1 $\mathrm{mm}$ 정도 띄워서 제작하도록 하고, 특히 구개측에 골성 고정원을 위치시킨 뒤 상악 전치에 인공치를 위치시킬 경 우, 치은이 과도하게 증식할 수 있으므로 유의해야 한다. 본 증례에서는 인공치와 골성 고정원 주변으로 환아에게 치실과 구강 세척기 등을 사용하도록 교육하였고, 3 - 4 개월마다 장치를 제거하여 청소한 후, 재접착하여 구강 위생이 유지될 수 있도록 하였다.

\section{결론}

본 증례는 선천 결손된 하악 치아를 가진 성장기 아동 에서 교정용 골성 고정원을 이용한 임시 보철 수복을 시 행한 증례로서, 치료 후 2 년동안 경과 관찰하였다. 결손 공간에 교정용 골성 고정원(TADs)을 치조골에 수평하 게 식립하였으며, 상방에 인공치를 제작하여 호선으로 고정하였다. 경과 관찰 기간 동안 골성 고정원 주변으로 염증 등은 관찰되지 않았으며, 인접 치조골의 수직 성장 저하 등은 나타나지 않았다. 또한 방사선 평가에서, 결손 공간의 유지와 치조골 폭경이 확연한 소실을 보이지 않 고 보존될 수 있었다.

\section{Acknowledgements}

본 연구는 2020년도 부산대학교 병원 임상연구비 지
원으로 이루어졌음(This work was supported by clinical research grant from Pusan National University Hospital in 2020).

\section{ORCID}

Youn-kyung Choi https://orcid.org/0000-0003-1491-2986

Eun-young Kwon https://orcid.org/0000-0001-9555-0360

Kyung-hwa Jung https://orcid.org/0000-0002-8305-0016

Na-Rae Choi https://orcid.org/0000-0002-5251-0825

Soo-Byung Park https://orcid.org/0000-0002-9774-9178

Seong-sik Kim https://orcid.org/0000-0003-1988-6043

Yong-il Kim https://orcid.org/0000-0003-3889-2545

\section{References}

1. Goya HA, Tanaka S, Maeda T, Akimoto Y. An orthopantomographic study of hypodontia in permanent teeth of Japanese pediatric patients. J Oral Sci 2008;50:143-50.

2. Polder BJ, Van't Hof MA, Van der Linden FP, Kuijpers-Jagtman AM. A meta-analysis of the prevalence of dental agenesis of permanent teeth. Community Dent Oral Epidemiol 2004;32:217-26.

3. Korean Academy of Pediatric Dentistry. Pediatric adolescent dentistry. 5th ed. Yenang Inc; Seoul; 2014. p. 566-9.

4. Kokich VG, Kokich VO. Congenitally missing mandibular second premolars: clinical options. Am J Orthod Dentofacial Orthop 2006;130:437-44.

5. Thilander B, Odman J, Lekholm U. Orthodontic aspects of the use of oral implants in adolescents: a 10-year follow-up study. Eur J Orthod 2001;23:71531.

6. Fudalej P, Kokich VG, Leroux B. Determining the cessation of vertical growth of the craniofacial structures to facilitate placement of singletooth implants. Am J Orthod Dentofacial Orthop 2007;131 Suppl 4:S59-67.

7. Olsen TM, Kokich VG Sr. Postorthodontic root approximation after opening space for maxillary lateral incisor implants. Am J Orthod Dentofacial Orthop 2010;137:158.e1-8.

8. Jeong DM, Choi B, Choo H, Kim JH, Chung KR, 
Kim SH. Novel application of the 2-piece orthodontic C-implant for temporary crown restoration after orthodontic treatment. Am J Orthod Dentofacial Orthop 2011;140:569-79.

9. Kokich VG, Swift EJ Jr. Temporary restoration of maxillary lateral incisor implant sites. J Esthet Restor Dent 2011;23:136-7.

10. Bollero P, Fazio V, Pavoni C, Cordaro M, Cozza $\mathrm{P}$, Lione R. Titanium alloy vs. stainless steel miniscrews: an in vivo split-mouth study. Eur Rev Med Pharmacol Sci 2018;22:2191-8.

11. Melsen B, Huja SS, Chien HH, Dalstra M. Alveolar bone preservation subsequent to miniscrew implant placement in a canine model. Orthod Craniofac Res 2015;18:77-85.

12. Ciarlantini R, Melsen B. Semipermanent replacement of missing maxillary lateral incisors by miniimplant retained pontics: A follow-up study. Am J Orthod Dentofacial Orthop 2017;151:989-94.

13. Hunter CJ. The correlation of facial growth with body height and skeletal maturation at adolescence. Angle Orthod 1966;36:44-54.

14. Baccetti T, Franchi L, McNamara Jr JA. The cervical vertebral maturation (CVM) method for the assessment of optimal treatment timing in dentofacial orthopedics. Semin Orthod 2005;11:119-29.

15. Nguyen T, Cevidanes L, Franchi L, Ruellas A, Jackson T. Three-dimensional mandibular regional superimposition in growing patients. Am J Orthod Dentofac Orthop 2018;153:747-54.

16. Johnson K. A study of the dimensional changes occurring in the maxilla following tooth extraction. Aust Dent J 1969;14:241-4.

17. Schropp L, Wenzel A, Kostopoulos L, Karring T. Bone healing and soft tissue contour changes following single-tooth extraction: a clinical and radiographic 12-month prospective study. Int J Periodontics Restorative Dent 2003;23:313-23.

18. Ostler MS, Kokich VG. Alveolar ridge changes in patients congenitally missing mandibular second premolars. J Prosthet Dent 1994;71:144-9.

19. Bertl K, Bertl MH, Heimel P, Burt M, Gahleitner A, Stavropoulos A, Ulm C. Alveolar bone resorption after primary tooth loss has a negative impact on straightforward implant installation in patients with agenesis of the lower second premolar. Clin Oral Implants Res 2018;29:155-63.

20. Williams P, Travess H, Sandy J. The use of osseointegrated implants in orthodontic patiens: I. Implants and their use in children. Dent Update 2004; 31:287-90.

21. Gill DS, Jones S, Hobkirk J, Bassi S, Hemmings K, Goodman J. Counselling patients with hypodontia. Dent Update 2008;35:344-52. 


\title{
성장기 아동에서 교정용 골성 고정원을 이용한 선천 결손 하악 전치의 임시 보철 수복: 2년 경과 관찰
}

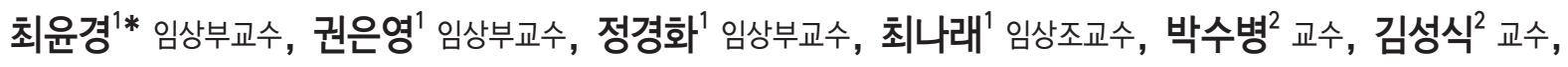 \\ 김용일 ${ }^{2}$ 부교수 \\ ${ }^{1}$ 부산대학교병원 치과진료센터 \\ ${ }^{2}$ 부산대학교 치의학전문대학원 치과교정과
}

영구치가 선천 결손된 아동에서 유치가 발거되면, 교정적으로 공간을 폐쇄하거나, 성장이 끝나고 임플란트 수복을 시행 할 때까지 공간을 유지하게 된다. 그러나 점차 치조골은 위축되고, 향후 보철 수복을 어렵게 하거나 비심미적인 결과를 야기할 수 있으므로, 임상의는 결손 공간과 치조골의 유지 모두 고려해야 한다. 본 증례에는 2 개의 하악 전치가 결손된 환아에서 교정용 골성 고정원을 이용한 임시 보철 수복을 시행한 증례이다. 2 개의 골성 고정원을 치조정 $2-3 \mathrm{~mm}$ 하방 에 수평으로 식립하였으며, 강선이 삽입된 인공치로 고정하였다. 2 년의 경과 관찰동안 치은 염증이나 골성 고정원의 탈락 은 발생하지 않았다. 또한 방사선 평가에서 인접 치조골의 성장이 저해되지 않았으며, 치조골 폭경 역시 양호하게 유지되 었다.

(구강회복응용과학지 2020;36(4):272-81)

주요어: 치조골 소실; 치아 결손; 임플란트; 임시 수복; 청소년기

*교신저자: 최윤경

(49241) 부산시 서구 구덕로 179 부산대학교병원 치과진료센터

Tel: 051-240-7430 | Fax: 051-240-7706 | E-mail: youngyng@hanmail. net

접수일: 2020년 10월 28일 | 수정일: 2020년 11월 10일 | 채택일: 2020년 12월 4일 